\title{
Effect of bevel angle of three-layer parallel plate on hydrodynamic performances of otter-board
}

\author{
Lei WANG, Lu Min WANG, Yu ZHANG, Ai Zhong ZHOU, Yong Li LIU, Wen Wen YU, Xun ZHANGa \\ Key Laboratory of Oceanic and Polar Fisheries, Ministry of Agriculture; East China Sea Fisheries Research Institute, Chinese \\ Academy of Fishery Sciences, Shanghai 200090, China
}

\begin{abstract}
The effect of bevel angle of three-layer parallel plate of otter-board on hydrodynamic performances is investigated by model wind tunnel test. Four otter-board models are designed with four different bevel angles $\left(8^{\circ}, 10^{\circ}, 12^{\circ}\right.$ and $\left.14^{\circ}\right)$, and tested under the wind speed $28 \mathrm{~m} / \mathrm{s}$ in wind tunnel. Model experiment is conducted to obtain the drag coefficients $\mathrm{C}_{\mathrm{x}}$, the lift coefficient $\mathrm{C}_{\mathrm{y}}$, the pitch moment coefficient $\mathrm{C}_{\mathrm{m}}$, the center of pressure coefficient $\mathrm{C}_{\mathrm{p}}$ and calculated the lift-drag ratio $\mathrm{C}_{\mathrm{y}} / \mathrm{C}_{\mathrm{x}}$. The result shows that the maximum lift coefficient and the maximum lift-drag ratio of the otter-board model with a bevel angle 12 degree is higher, there is $2.598\left(\alpha=65^{\circ}\right)$ and $2.607\left(\alpha=37.5^{\circ}\right)$; For comparison in stability of otter-board, the stability of the otter-board model with the bevel angle 8 degree is better by the comparative analysis of $C_{m}$ and $C_{p}$, the absolute value of $C_{m}$ is 0.174 and the minimum variation coefficient of $C_{p}$ is $4.37 \%$. The results can offer reference for the structural optimization design of trawl otter-board.
\end{abstract}

\section{Introduction}

Trawl doors is an important member of fishing gear for spread of trawl. The merits of otter-board hydrodynamic performance can be measured by the lift coefficient of the trawl door, the drag coefficient of the trawl door and pitching moment coefficient of the trawl door [1]. By optimizing the structure of otter-board may improve hydrodynamic performance of the otter-board, and reducing the energy consumption of fishing vessels [2-3]. Currently, extensive studies on otter-board hydrodynamic performance had been conducted in the US, Japan, Norway and other countries [4-9]; In China, researchers have studied the relevant hydrodynamic performance of otterboard early since $1980 \mathrm{~s}$, and the series of optimization studies on otter-board structure is still necessary [10-15]. With the development of offshore fishing, higher requirements on the otter-board design is put forward, hydrodynamic performance improvement of otter-board will be the focus of future research. This article is part of the series of tests, which analyze the hydrodynamic performance of otter-board with the bevel angle of threelayer parallel plate changing.

\section{Material and Methods}

\subsection{Design and manufacture of otter-board model}

Test model of otter-board with three parallel plates is designed in different bevel angle of the three parallel plates.
Ensuring the premise of other parameters in common, the design of model structure has been simplified based on the test objectives and requirements, while, only the bevel angle of three parallel plates changes. The structure and parameters of the model are illustrated in figure 1 .

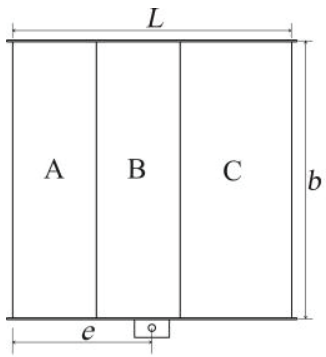

Front view
Top view

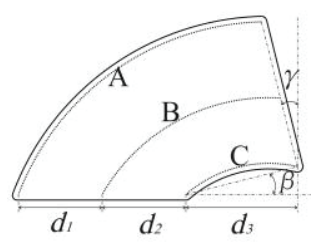

Figure 1 Structure and parameters of otter-board

Note: $L$ : chord; $b$ : span; $e$ : distance between fulcrum and front end of model; A, B, C: parallel plate; $\gamma$ : bevel angle; $\beta$ : angle of front plate; $d_{l}$ : horizontal distance between $\mathrm{A}$ and $\mathrm{B} ; d_{2}$ : horizontal distance between $\mathrm{B}$ and $\mathrm{C}$; $d_{3}$ : projected length of $\mathrm{C}$.

For four otter-board test models, the aspect ratio is fixed at 1.0 , model's area is $0.250 \mathrm{~m} 2$, the corresponding distance between plate A-B-C and each projected length of plate $\mathrm{C}$ are same, when the bevel angle of three parallel plates changes four angle $(8,10,12$ and 14), the curvature of the plate $\mathrm{C}$ is $12 \%$, the specific parameters in table 1 , four otter-board models are numbered 1, 2, 3, 4 respectively. Models are made of steel with painted

a Corresponding author: zhangxun007@hotmail.com 
surfaces (figure 2).

Table 1 Introductions for dimension and structure parameters of four otter-board models

\begin{tabular}{cccccccccc}
\hline No. & $L / \mathrm{m}$ & $b / \mathrm{m}$ & $\lambda$ & $S / \mathrm{m}^{2}$ & $e / \mathrm{m}$ & $d_{I}=d_{2} / \mathrm{m}$ & $d_{3} / \mathrm{m}$ & $\gamma=\beta$ & $\delta$ \\
\hline 1 & 0.50 & 0.50 & 1.0 & 0.250 & 0.25 & 0.15 & 0.20 & $8^{\circ}$ & 0.12 \\
2 & 0.50 & 0.50 & 1.0 & 0.250 & 0.25 & 0.15 & 0.20 & $10^{\circ}$ & 0.12 \\
3 & 0.50 & 0.50 & 1.0 & 0.250 & 0.25 & 0.15 & 0.20 & $12^{\circ}$ & 0.12 \\
4 & 0.50 & 0.50 & 1.0 & 0.250 & 0.25 & 0.15 & 0.20 & $14^{\circ}$ & 0.12 \\
\hline
\end{tabular}

Note: $b$ : span; $L$ : chord; $\lambda=b / L$, aspect ratio; $S=L \cdot b ; e$ : distance between fulcrum and front end of model; $d_{l}$ : horizontal distance between $\mathrm{A}$ and $\mathrm{B} ; d_{2}$ : horizontal distance between $\mathrm{B}$ and
$\mathrm{C} ; d_{3}$ : projected length of $\mathrm{C} ; \gamma$ : bevel angle; $\beta$ : angle of plate $\mathrm{C} ; \delta$ : curvature of plate $\mathrm{C}$.

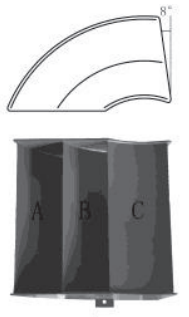

1
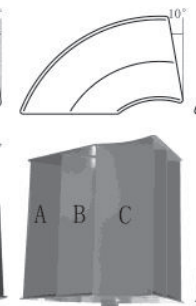

2

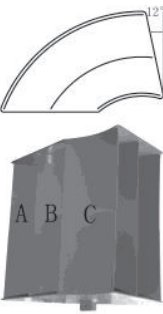

3
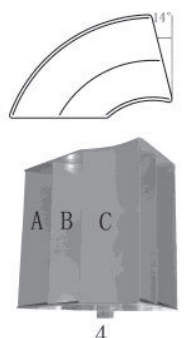

4

Note: A, B, C: parallel plate.

Figure 2 Four otter-board models and top view of design

\subsection{Test facility}

Wind tunnel for this test is Nanjing University of Aeronautics and Astronautics NH-2 wind tunnel, the tunnel is closed reflux wind tunnel with double string test section, this experiment is carried out in a small test section, the main technical performance of the small test section: $6 \mathrm{~m}$ (length) $\times 3 \mathrm{~m}$ (width) $\times 2.5 \mathrm{~m}$ (height), import crosssectional area $7.18 \mathrm{~m}^{2}$, the maximum wind speed is $90 \mathrm{~m} /$ $\mathrm{s}$, the minimum steady wind speed is $5 \mathrm{~m} / \mathrm{s}$.

The dynamometer test uses six-component mechanical tower - Balances to measure, test model installation is shown in figure 3.

Test data acquisition and processing system used is made up by the pre-amplifier and four networked computer system.

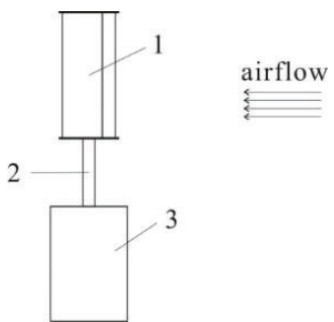

Figure 3 Installation instruction of otter-board model in wind tunnel

Note: 1.otter-board model 2.model connection 3.six-component force balance

\subsection{Test method}

\subsubsection{Parameter definition of test model}

Test models need to be installed on the wind tunnel in six-component balance mechanical base according to the order, angle of attack of model rotates by the $0^{\circ}-70^{\circ}$ when the wind speed reaches $28 \mathrm{~m} / \mathrm{s}$ (room temperature $20{ }^{\circ} \mathrm{C}$ ), wherein the angle of attack in the range $0^{\circ}-50^{\circ}$, $2.5^{\circ}$ intervals to record a measurement data point, after the attack angle $50^{\circ}$, each measurement interval of $5^{\circ}$ to record data points, there are 25 sets of data totally, including the drag coefficient $C_{x}$, the lift coefficient $C_{y}$, the pitch moment coefficient $C_{\mathrm{m}}$ and the center of pressure coefficient $C_{\mathrm{p}}$.

The relevant parameters of models in the wind tunnel test section are defined as shown in figure 4 . In figure $4, \mathrm{O}$ is torque reference point, which is the punch of the model at the bottom. During the test, the resistance of the model is provided by the force of balance along the $\mathrm{X}$-axis direction, the lift is provided by the force of balance along the $\mathrm{Z}$-axis direction, and the pitch moment is provided by the $M_{\mathrm{y}}$ of balance along the $\mathrm{Z}$-axis direction.

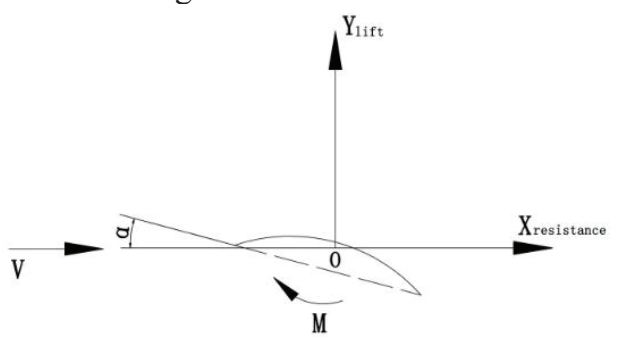

Figure 4 Parameter definition diagram of test model in wind tunnel

For this test, Wind speed $V=28 \mathrm{~m} / \mathrm{s}$, when the Reynolds number $R_{e}=V L / v=0.93 \times 10^{6} \quad$ (coefficient of viscosity $\left.v=15 \times 10^{6} \mathrm{~m}^{2} \cdot \mathrm{s}^{-1}\right)[10]$.

\subsubsection{Parameter definition of test measurement}


Three components: lift $Y$, drag $X$, pitching moment $M$ (around the fulcrum), while the distance from the center of pressure to the front-end otter-board $d=e-(M / N)$ [12], $(N$ is the normal force).

Lift coefficient $C_{y}=\frac{Y}{\rho V^{2} S / 2}[3]$; drag coefficient $C_{x}=\frac{X}{\rho V^{2} S / 2} ;$ pitch moment coefficient ${ }_{C_{m}}=\frac{M}{\rho V^{2} S L / 2}$; center of pressure coefficient $C_{p}=\frac{d}{L}$.

Air density $\rho=1.225 \mathrm{~kg} / \mathrm{m}^{3}$ in above formula; $S$ is otterboard area $\left(\mathrm{m}^{2}\right) ; L$ is the otter-board chord length $(\mathrm{m})$.

All the experimental data have been carried out the stent disturbance correction which is completed by the method of taking out light pole directly.

\section{Results and Discussion}

\subsection{Drag coefficient and lift coefficient}

Data from the experiment includes the drag coefficient $C_{x}$, the lift coefficient $C_{y}$, the pitch moment coefficient $C_{\mathrm{m}}$ and the center of pressure coefficient $C_{p} . C_{y} / C_{x}$ is the lift-drag ratio, which is an important factor to determine the merits of otter-board hydrodynamic performance. Otter-board with excellent hydrodynamic properties will get higher liftdrag ratio and better stability, what can be analyzed by comparing the pitching moment coefficient $C_{\mathrm{m}}$ stencil and the center of pressure coefficient $C_{p}[1-3]$. The test data is divided and made $C_{x}-\alpha, C_{y}-\alpha$ and $C_{y} / C_{x}-\alpha$ graph shown in figure 5 for analyzing the differences of hydrodynamic properties of four otter-board models clearly.

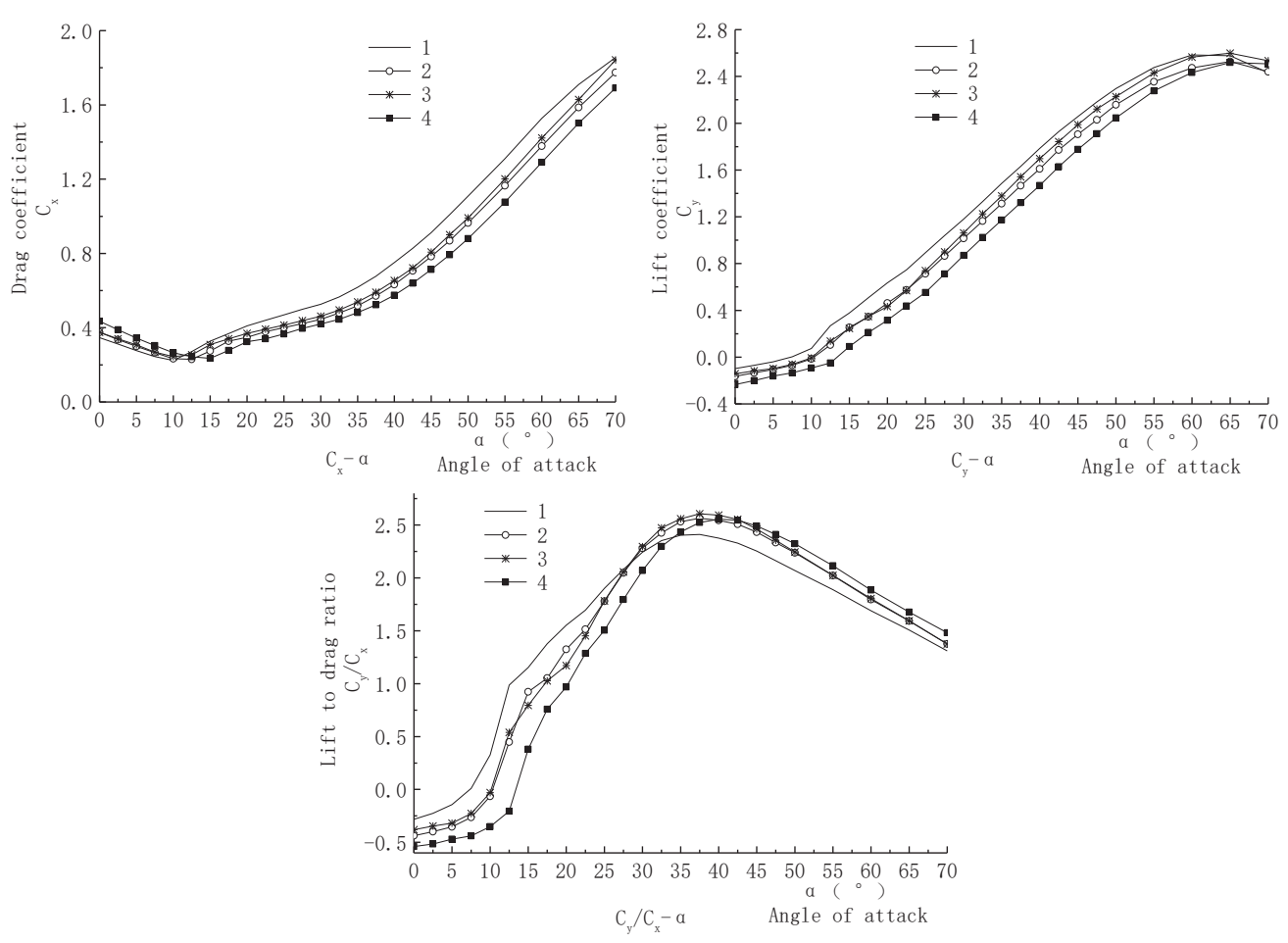

Figure 5 The changing curve comparison of $C_{\mathrm{x}}(\mathrm{a}), C_{\mathrm{y}}(\mathrm{b})$ and $C_{\mathrm{y}} / C_{\mathrm{x}}(\mathrm{c})$ along with the angle of attack $\alpha$

In figure 5, graph $C_{x}-\alpha$ and $C_{y}-\alpha$ show the variation curve of drag coefficient $C_{x}$ and lift coefficient of four models while the angle of attack $\alpha$ changed. The relationship between $C_{x}$ and $\alpha$ is proportional, No.1 otterboard model with the bevel angle of $8^{\circ}$ has the higher drag coefficient. The maximum lift coefficient $C_{y}$ of No. 3 model is higher, there is $2.598\left(\alpha=65^{\circ}\right)$, and the maximum lift coefficient of No. 1 and No. 2 otter-board model are $2.583\left(\alpha=60^{\circ}\right)$ and $2.527\left(\alpha=65^{\circ}\right)$, the maximum lift coefficient $C_{y}$ of No. 4 model is the lowest, there is 2.519 $\left(\alpha=65^{\circ}\right)$.

\subsection{Lift-drag ratio}

The lift-drag ratio can be more intuitive to analysis the hydrodynamic performance of otter-board, and the otterboard with higher lift-drag ratio gets the better operational efficiency. In figure 5, the curve $C_{y} / C_{x}-\alpha$ indicates that the lift-drag ratio $C_{y} / C_{x}$ of No. 1 otter-board model with the bevel angle of $8^{\circ}$ is higher at the angle of attack $\alpha<27.5^{\circ}$, and the maximum lift-drag ratio is $2.411\left(\alpha=37.5^{\circ}\right)$, the maximum lift-drag ratio of No. 2 and No. 4 model is 2.564 $\left(\alpha=37.5^{\circ}\right)$ and $2.555\left(\alpha=40^{\circ}\right)$, respectively; however, the maximum lift-drag ratio $C_{y} / C_{x}$ of No. 3 otter-board model with the bevel angle of $12^{\circ}$ is higher than the other three models, there is $2.607\left(\alpha=37.5^{\circ}\right)$.

\subsection{Stability of otter-board}

Pitching moment, also known as longitudinal moment, what is the component along the horizontal axis of the moment of force that is generated by the aerodynamic acting on the otter-board to the center of gravity of model, and the pitching moment coefficient $C_{m}$ is usually converted for analysis and comparison instead. Pitching moment can be divided into upper and lower pitching 
moment, what are usually distinguished by positive and negative, its absolute value represents the level of pitching moment, and the pitching moment coefficient tending to 0 represents the more excellent stability of otter-board generally, in practice, comparing the absolute value $C_{m}$ corresponding to the operation angle of attack of otterboard may determine the stability level of otter-board. For comparison, it is assumed to select the angle of attack corresponding to the maximum lift-drag ratio $C_{\mathrm{y}} / C_{\mathrm{x}}[16]$, when the absolute value of $C_{m}$ corresponded is shown in table 2. The absolute value of $C_{m}$ of No.1 model is 0.174 , so the stability of No.1 otter-board model is better.

Table 2 Parameters of four otter-board for stability analysis

\begin{tabular}{|c|c|c|c|}
\hline No. & $\begin{array}{c}\text { Angle corresponding } \\
\text { to the maximum lift - } \\
\text { drag ratio } \\
\alpha\end{array}$ & $\left|C_{\mathrm{m}}\right|$ & $\begin{array}{c}\text { Variable } \\
\text { coefficient of } C_{\mathrm{p}}\end{array}$ \\
\hline 1 & $37.5^{\circ}$ & 0.174 & $4.37 \%$ \\
\hline 2 & $37.5^{\circ}$ & 0.194 & $4.70 \%$ \\
\hline 3 & $37.5^{\circ}$ & 0.183 & $5.17 \%$ \\
\hline 4 & $40^{\circ}$ & 0.191 & $4.99 \%$ \\
\hline
\end{tabular}

The stability of otter-board can be measured by the center of pressure coefficient $C_{\mathrm{p}}$, and it is generally compared by analyzing the coefficient of variation of $C_{\mathrm{p}}$ within the range of angle around $5^{\circ}$ of the angle of attack corresponding to the maximum lift-drag ratio, the smaller the coefficient, the better the stencil stability [17]. Data Calculated is shown in table 2 , the minimum variation coefficient of $C_{\mathrm{p}}$ is $4.37 \%$, and it also means the stability of No.1 otter-board model is better.

\section{Conclusion}

The test study concludes that designing the bevel angle of otter-board plates appropriately can improve the lift coefficient of the otter-board. When the bevel angel of three parallel plates of otter-board is designed in $8^{\circ}$ or $12^{\circ}$, the otter-board has the higher maximum lift coefficient. It is also needed to pay attention to adjust the lift -drag ratio and stability of the otter-board, test shows that the maximum lift-drag ratio of otter-board model with the bevel angle of $12^{\circ}$ is higher than the other three models, and the stability of the otter-board model with the bevel angle of $8^{\circ}$ is better. Data and conclusions of this study can provide a reference for the design of otter-board.

\section{Acknowledgements}

This work is financially supported by the National Key Technology R\&D Program (No. 2013BAD13B05).

\section{References}

1. Guo G X, Liu TY, Huang X H, Gu F L. Theory and Practice of trawl doors Kinetic [M]. Guangdong Science and Technology Publications, 2008.

2. Zhou Y Q. Mechanics of fishing gear [M]. China Agriculture Publications, 2001.

3. Chen X Z, Huang X C. Theory and method of gear model test $[\mathrm{M}]$. Shanghai Science and Technology Publications, 2011.

4. Sala A, Prat J, Antonijuan J, Lucchetti A. Performance and impact on the seabed of an existingand an experimental-otter board: Comparison between model testing and full-scale sea trials [J]. Fisheries Research, 2009, 100(2): 156-166.

5. Takahashi Y, Fujimori Y, Hu F X, Shen X L, Kimura N. Design of trawl otter boards using computational fluid dynamics [J]. Fisheries Research, 2015, 161: 400-407.

6. Shen X L, Hu F X, Kumazawa T, Shiode D, Tokai T. Hydrodynamic characteristics of a hyper-lift otter board with wing-end plates $[\mathrm{J}]$. Fisheries Science, 2015, 81(3): 433-442.

7. Broadhurst M K, Sterling D J, Millar R B. Modifying otter boards to reduce bottom contact: Effects on catches and efficiencies of triple-rigged penaeid trawls [J]. Fisheries Management and Ecology, 2015, 22(5): 407-418.

8. Fukuda K, Hu F X, Tokai T, Matuda K. Effect of Aspect Ratio on Lift and Drag Coefficients of Cambered Plates [J]. Nippon Suisan Gakkaishi, 2000, 66(1): 97-103.

9. Park C D, Matuda K, Hu F X. Effects of Dihedral and Sweepback Angles on Lift and Drag of the Cambered Otter Board [J]. Nippon Suisan Gakkaishi, 1996, 62(6): 920-927.

10. Zhang X, Wang J H, Wang M Y, Yu Y F, Xu, B. S. Hydrodynamic characteristics of rectangular cambered V type otter board-- I : Relationship between cambered ratio of fairwater fin and hydrodynamic characteristics of otter board [J]. Journal of Fishery Sciences of China, 2004, 11(z1): 5-8.

11. Wang J H, Wang M Y, Zhang X, Yu Y F, Xu B S. Hydrodynamic characteristics of rectangular cambered V type otter board-- II : Effects of aspect ratio, slotted position and slotted width on hydrodynamic characteristics of otter board [J]. Journal of Fishery Sciences of China, 2004, S1: 9-13.

12. Wang M Y, Wang J H, Zhang X, Yu Y F, Xu B S. Hydrodynamic characteristics of vertical $V$ type otter board [J]. Journal of Fisheries of China, 2004, 3: 311 315.

13. Li C C, Liang Z L, Huang L Y, Zhou W F, Sun P, Wang L. Hydrodynamic study on a vee type otter board of small trawl vessels [J]. Marine Sciences, 2013, 11: 69-73.

14. Wang L, Wang L M, Feng C L, Zhang X, Shi J G, Zhang Y, Liu Y L, Yu W W. Influence of vane dimension on hydrodynamic performances of single slotted cambered otter board [J]. Fishery Modernization, 2015, 6: 55-60.

15. Wang L, Wang L M, Yu W W, Feng C L, Shi J G, Liu Y L, Zhang X. Influence of deflector angular variation on hydrodynamic performances of single slotted cambered otter board [C]. Conference: International Forum on Energy, Environment and Sustainable Development, 2016, 75: 530-535.

16. Yang L. Hydrodynamic characteristics of slotted 
circular plate $[\mathrm{J}]$. Fisheries Science and Technology, 1996, 2: 38-41.

17. Yang L. Hydrodynamic characteristics of double plate circular plate $[\mathrm{J}]$. Fisheries Science and Technology, 1996, 5: 42-44. 